\title{
教育講演
}

\section{9. 新規抗菌薬の開発}

\author{
松本 哲哉
}

Key words : 新規抗菌薬, 耐性菌, 創薬促進, ドラッグ・ラグ, 抗菌薬の適正使用

\section{はじめに}

抗菌薬はこれまで多くの恩恵を人々にもたら してきた，以前は死因の上位を占めていた各種 の感染症は抗菌薬が一般的に使用されるように なってから激減し, 感染症の脅威は去ったかの ように思えた。しかし, 現在でも感染症の問題 は克服されておらず，逆に今後，深刻になる可 能性が大きいことが指摘されている，その一方 で，抗菌薬の開発は明らかに衰退しており，感 染症に対抗できる新たな手段に期待できなくなっ てきている，そこで本稿では，私たちを取り巻 く感染症の状況を踏まえて, 今後, なぜ新規抗 菌薬の開発に注力する必要があるのかについて 解説する。

\section{1. 抗菌薬によってもたらされた恩恵}

これまでの感染症の歴史をさかのぼってみる と, 人類が感染症の治療薬として抗菌薬を使え るようになったのは 1940 年代以降である.最初
に 1928 年にAlexander Flemingがペニシリンを 発見し, Ernst B. Chain とHoward Walter Florey が薬として実用化するまで十数年を要している. しかし，これが発端となって抗菌薬の開発は黎 明期を迎え，各種の抗菌薬が開発され，臨床の 現場で広く使用可能となった（表 1 )。さらに各 種のワクチンも使用可能となり, 衛生環境の改 善も伴って 1940 年代頃まで世界的に死因の上位 を占めていた肺炎や結核，消化管感染症などの 主要な感染症はその後激減した。これにより社 会全体に感染症はすでに制圧されたかのような 䨌囲気が広がり，「感染症の時代は終わった」と いう考えも広まった。

\section{2. 現在の感染症の状況と必要とされる方 策}

抗菌薬の開発などによって感染症が制圧され てしまったかというと，実際はまだ現在でも世 界の死因の約 4 分の 1 は感染症で占められてい る. 最近の世界的な死因の統計結果 ${ }^{1)}$ (図 1)を見 てみると，各種の感染症がいまだに死因の上位

東京医科大学微生物学分野

111th Scientific Meeting of the Japanese Society of Internal Medicine : Educational Lecture : 9. Discovery and development of new antimicrobial agents.

Tetsuya Matsumoto : Department of Microbiology, Tokyo Medical University, Japan.

本講演は, 平成 26 年 4 月 12 日（土）東京都・東京国際フォーラムにて行われた. 
表 1. 抗菌薬開発の歴史

\begin{tabular}{|c|c|c|c|c|c|c|c|}
\hline 系統 & \begin{tabular}{|c|}
1940 \\
年代
\end{tabular} & $\begin{array}{l}1950 \\
\text { 年代 }\end{array}$ & $\begin{array}{l}1960 \\
\text { 年代 }\end{array}$ & $\begin{array}{l}1970 \\
\text { 年代 }\end{array}$ & $\begin{array}{l}1980 \\
\text { 年代 }\end{array}$ & $\begin{array}{l}1990 \\
\text { 年代 }\end{array}$ & $\begin{array}{l}2000 \\
\text { 年以降 }\end{array}$ \\
\hline ペニシリン & ペニジ & & $\begin{array}{l}\text { アンピシリン } \\
\text { オキサシリン }\end{array}$ & アモキシシリン & $\begin{array}{c}\text { ピペラシリン } \\
\text { アモキシシリン/ } \\
\text { クラブラン酸 }\end{array}$ & $\begin{array}{c}\text { スルバク多ム/アンピ } \\
\text { シリンン }\end{array}$ & ピペラシリン/タゾバ \\
\hline セフェム & & & セファロチン & $\begin{array}{l}\text { セフアン゙リン } \\
\text { セフアルキシン }\end{array}$ & $\begin{array}{l}\text { セファクロル } \\
\text { セフメノキシム } \\
\text { セフメタゾール } \\
\text { セフォチアム } \\
\text { セフォタキシム } \\
\text { セフォペラゾン } \\
\text { セフトリアキソン } \\
\text { セフタジジム } \\
\text { セフポドキシム } \\
\text { ラタモキセフ } \\
\text { フロモキセフ }\end{array}$ & $\begin{array}{l}\text { セフジニル } \\
\text { セフピロム } \\
\text { セフェピム } \\
\text { セフォゾプラン } \\
\text { セフジトレン } \\
\text { セフカペン }\end{array}$ & \\
\hline カルバペネム & & & & & イミペネム & $\begin{array}{l}\text { パニペネム } \\
\text { メロペネム }\end{array}$ & $\begin{array}{l}\text { ドリペネム } \\
\text { ビアペネム } \\
\text { テビペネム }\end{array}$ \\
\hline モノバクタム & & & & & アズトレオナム & & \\
\hline ホスホマイシン & & & & & ホスホマイシン & & \\
\hline キノロン & & & & & $\begin{array}{c}\text { ノルフロキサシン } \\
\text { オフロキサシン } \\
\text { シプロフロキサシン }\end{array}$ & \begin{tabular}{|} 
トスフロキサシン \\
スパルフロキサシン \\
レボフロキサシン
\end{tabular} & $\begin{array}{l}\text { ガチフロキサシン } \\
\text { パズフロキサシン } \\
\text { プルリワロキサシン } \\
\text { モキシフロキサシン } \\
\text { ガレノキサシン } \\
\text { シタフロキサシン }\end{array}$ \\
\hline マクロライド & & エリズマ & & ジョサマイシン & ロキタマイシン & $\begin{array}{l}\text { クラリスロロマイシン } \\
\text { ロキシスロマイシン }\end{array}$ & アジスロマイシン \\
\hline リンコマイシン & & & & クリンダマイシン & & & \\
\hline テトラサイクリン & & & & \begin{tabular}{|l} 
ミノサイクリン \\
ドキシサイクリン
\end{tabular} & & & \\
\hline アミノグリコシド & & $\begin{array}{c}\text { ㅈレプ } \\
\text { マイシン } \\
\text { カナマイシ } \\
\text { ン }\end{array}$ & & $\begin{array}{l}\text { ゲンタマイシン } \\
\text { トブラマイシン }\end{array}$ & $\begin{array}{c}\text { アミカシン } \\
\text { イセパマイシン }\end{array}$ & アルベカシン & \\
\hline サルファ剂 & & & & ST合剤 & & & \\
\hline グリコペプチド & & & & & バンコマイシン & テイコプラニン & \\
\hline ストレプトグラミン & & & & & & & $\begin{array}{c}\text { キヌプリスチン/ダル } \\
\text { ホプリスチン }\end{array}$ \\
\hline オキサゾリジノン & & & & & & & リネゾリド \\
\hline リポペプチド & & & & & & & ダフトマイシン \\
\hline ケトライド & & & & & & & テリスロマイシン \\
\hline
\end{tabular}




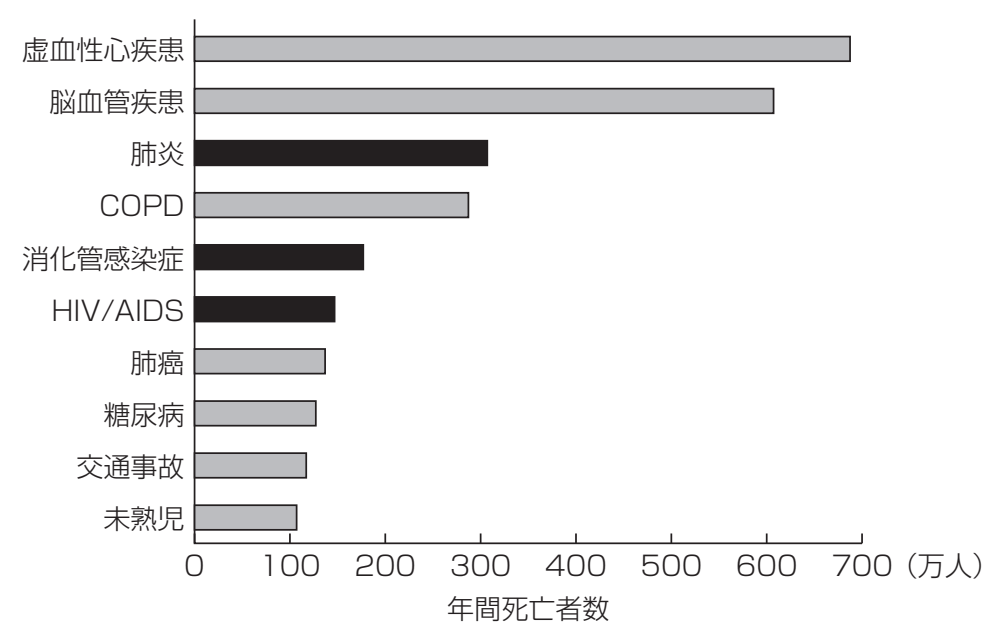

文献 2 より筆者作成

図 1.世界の 10 大死因（2011 年）

を占めており，それらを合わせると首位にも匹 敵するほどである. なぜ多くの抗菌薬が使用可 能になったにもかかわらず，いまだに感染症が 大きな問題となっているのか. その背景として は, (1)主に発展途上国における衛生環境や医療 体制の不備, (2)現時点で有効な治療薬がない感 染症の存在, (3)耐性菌の出現および増加などが 挙げられる。

感染症のこれらの課題に対して, 私たちが今 後さらに取り組まなければならないことは多々 ある。発展途上国に対してはグローバルヘルス 分野への貢献を目的として, 日本企業も各種薬 剂の開発に力を入れている。また，日本も含め て世界の国々が発展途上国の衛生環境や医療の 改善のための援助を行い, 感染による死亡率も 減少傾向を示している. しかし, 根本的には各 国の政情不安や貧困に絡んだ問題が大きいため, その問題の解決が重要と思われる.

有効な治療薬がまだ見つかっていない感染症 としては, 新興感染症として話題となっている 重症熱性血小板減少症候群 (severe fever with thrombocytopenia syndrome : SFTS) p中東呼 吸器症候群 (middle east respiratory syndrome: MERS) などが有名であり, さらにいまだに猛威
を振るっているデング熱などの各種感染症に対 しても有効な治療薬がなく, 今後の開発が期待 される。

耐性菌に対する対策の中には感染対策の徹底 による耐性菌の伝播の予防も含まれるが，それ だけでは限界があり,やはり耐性菌に有効な新 薬の開発も重要と考えられる.

\section{3. 耐性菌の問題の深刻化}

我が国においては, 多剂耐性黄色ブドウ球菌 (methicillin-resistant Staphylococcus aureus: MRSA)が 1980 年代から各医療機関で分離頻度 が増加し, 現在でも臨床現場で分離される耐性 菌のトップとなっている. さらに 2000 年代以降 は多剂耐性緑膿菌（multidrug-resistant Pseudomonas aeruginosa : MDRP) が院内感染の原因菌 として注目されるようになり, extended spectrum $\beta$-lactamase（ESBL）産生菌の分離例が国 内で急増している.さらに表 2 に示すように各 種の耐性菌が分離されており，院内だけでなく 市中の感染例でも耐性菌の存在が問題となって いる.

また，耐性菌の問題が深刻になっているもう 
表 2. 主な多剤耐性菌の特徵と最近の傾向

\begin{tabular}{|c|c|c|}
\hline 多剂而性菌 & 耐性を示す抗菌薬 & 傾向 \\
\hline MRSA & 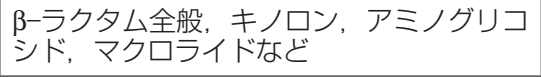 & $\begin{array}{l}\text { 米国で市中感染型が急増, 国内では院内感染 } \\
\text { 型が減少傾问 }\end{array}$ \\
\hline VRE & 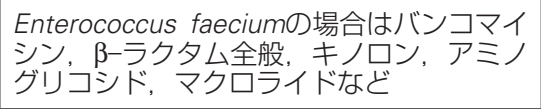 & $\begin{array}{l}\text { 欧米, アジアではすでに広く浸透, 国内では } \\
\text { まれ }\end{array}$ \\
\hline MDRP & 単独ではコリスチン以外はすべて耐性 & $\begin{array}{l}\text { アジアで増加傾向，国内は緑膿菌全体の数\% } \\
\text { 程度 }\end{array}$ \\
\hline ESBL産生菌 & ペニシリン, 第 1 リ 4 世代セファロスポ & アジアを中心に急増, 国内でも増加傾向 \\
\hline AmpC $\beta$-ラクタマーゼ産生菌 & ペニシリン, 第 1 リ 3 世代セファロスポ & $\begin{array}{l}\text { 欧米, アジアで増加. 国内では大腸菌, 肺炎 } \\
\text { 桿囷の数\%程度 }\end{array}$ \\
\hline 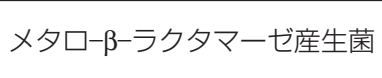 & 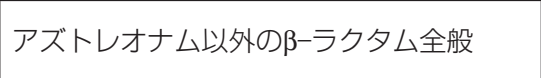 & $\begin{array}{l}\text { 緑膿菌における頻度が高いが, 腸内細菌科に } \\
\text { 多る傾向 }\end{array}$ \\
\hline 多剤耐性アシネトバクター & $\begin{array}{l}\text { コリスチン, チゲサイクリン以外はすべて } \\
\text { 而性 }\end{array}$ & 米国, アジア各国で急増，国内ではまれ \\
\hline NDM- 1 産生菌 & 当耐性 & $\begin{array}{l}\text { インドを中心に流行, その他世界各地で分離, } \\
\text { 国内ではごくまれ }\end{array}$ \\
\hline KPC産生菌 & $\begin{array}{l}\text { 尚性 } \\
\text { 性チン, チゲサイクリン以外はすべて }\end{array}$ & $\begin{array}{l}\text { 米国を中心に流行, その他世界各地で分離, } \\
\text { 国内ではごくまれ }\end{array}$ \\
\hline
\end{tabular}

1つの要因としては, 耐性を示す薬剤が広範囲に および，多剤耐性を示す菌が増加していること が挙げられる。そそ傾向が顕著なのがグラム陰 性菌であり, 多剂耐性アシネトバクター (multiple drug-resistant Acinetobacter : MDRA)は特に 海外で広がりを見せている。 また，カルバペネ 么耐性腸内細菌（carbapenem-resistant enterobacteriaceae：CRE)の増加が特に米国など海外 で深刻になってきている。これはNDM-1（New Delhi metallo-beta-lactamase-1) 産生菌やKPC (Klebsiella pneumoniae carbapenemase) 産生菌を 含んだ総称的な耐性菌の名称である. CREは感 染症の治療の切り札的存在であるカルバペネム 系抗菌薬が無効であり, 我々にとって身近な存 在である大腸菌や肺炎桿菌などの菌による感染 症の治療がCREの出現によってかなり困難になっ てきている.特に米国Centers for Disease Control and Prevention (CDC) はCREの増加に危機感を 募らせ,「悪魔の耐性菌（nightmare bacteria）」 と呼び, 警告を発している.

このように耐性菌は新たな耐性菌の出現とと
もに, 多くの抗菌薬に耐性を示す多剤耐性の菌 が増加する傾向にある。 また, 耐性菌の問題は 日本に比べて海外ではより深刻な状況にあり， 選択可能な抗菌薬がほとんど残されていない高 度な耐性菌も広がってきている。この状況を受 けてWorld Health Organization (WHO) は 2011 年に「世界的に耐性菌の問題は深刻な状況となっ ており，すぐにしかるべき対策を取らなければ 治療ができなくなる」旨のメッセージを発信し ている2).

\section{4. 耐性菌の問題に立ち向かうための方策}

上記のように耐性菌の問題が深刻になってき ている状況において，私たちがなすべきことが いくつか挙げられる. 米国感染症学会は耐性菌 に立ち向かうために重要な 4 つの手段として, (1)耐性菌の状況把握, (2)耐性菌の伝播防止, (3) 抗菌薬の適正使用, および(4)新規抗菌薬の開発 を挙げている ${ }^{3)}$.すなわち, 耐性菌の状況を知り, 広げないように対策を行い, 抗菌薬を適正に使 


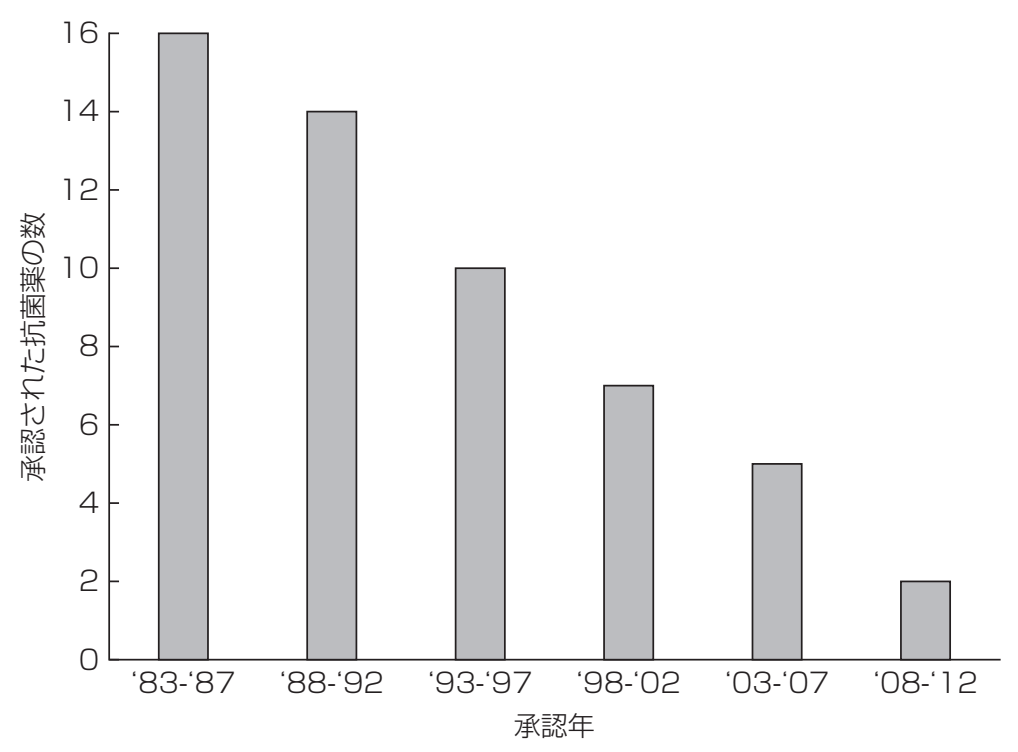

文献 3 をもとに一部改変

図 2. 米国で新しく承認を受けた抗菌薬の推移

用することで耐性菌のリスクを軽減することを 提言している，ただし，それらを全て実施した としても問題を解決できるわけではなく，新し い抗菌薬の開発も手段の 1 つに加えられている.

抗菌薬の開発については, 耐性菌の出現と抗 菌薬の開発は“いたちごっこ”であるという表 現がしばしば聞かれる。確かにこれまでの歴史 を見るとその傾向は否めない.ただし, 現在は その“いたちごっこ”さえできなくなってきて いるのが実状であり, 耐性菌の進化が抗菌薬開 発よりもかなり先を行き始めていると言える.

\section{5. 抗菌薬開発の歴史と現在の状況}

これまで抗菌薬の開発には多数の企業がしの ぎを削ってきた. 特に 1980 年代および 1990 年 代は国内外の製薬企業がこぞって抗菌薬の開発 を進め,さらに多くの抗菌薬が利用できるよう になった．特に日本の企業も様々な抗菌薬の開 発に貢献し，優れた抗菌薬を開発してきた ${ }^{4}$.し かし時代とともに抗菌薬の開発は陰りがさし, 現在では多くの製薬会社が開発から撤退してい
る.これにより新しく承認される抗菌薬の数も 顕著に減少している。この状況は図 2 に端的に 示されており，米国で承認された抗菌薬の数は 著明に減少している ${ }^{3)}$. 新しく承認される抗菌薬 がほとんどない状況は，米国だけでなく欧州や 日本でも認められる。この傾向は一時的な現象 とは考えられず, 今後も新規抗菌薬はほとんど 世に出ることは期待できない状況となっている.

\section{6. なぜ抗菌薬は開発されないのか?}

新しい抗菌薬がほとんど開発されなくなった 背景には，薬剤による収益の差が大きいと考え られる. すなわち, 図 3 に示すように 2013 年の 国内の売り上げトップ 10 を薬効別に比較してみ ると, 抗腫瘍薬がトップで, 高血圧, 糖尿病, 高脂血症などの慢性的な疾患の治療薬がそれに 続いている5). 抗菌薬は 7 番目に位置しているが, 収益そのものは他の薬剤に比べて低いのが現状 である，その理由としては，感染症は基本的に 急性疾患が大半を占めており，抗菌薬による治 療は比較的短期間のうちに終了することが多い. 


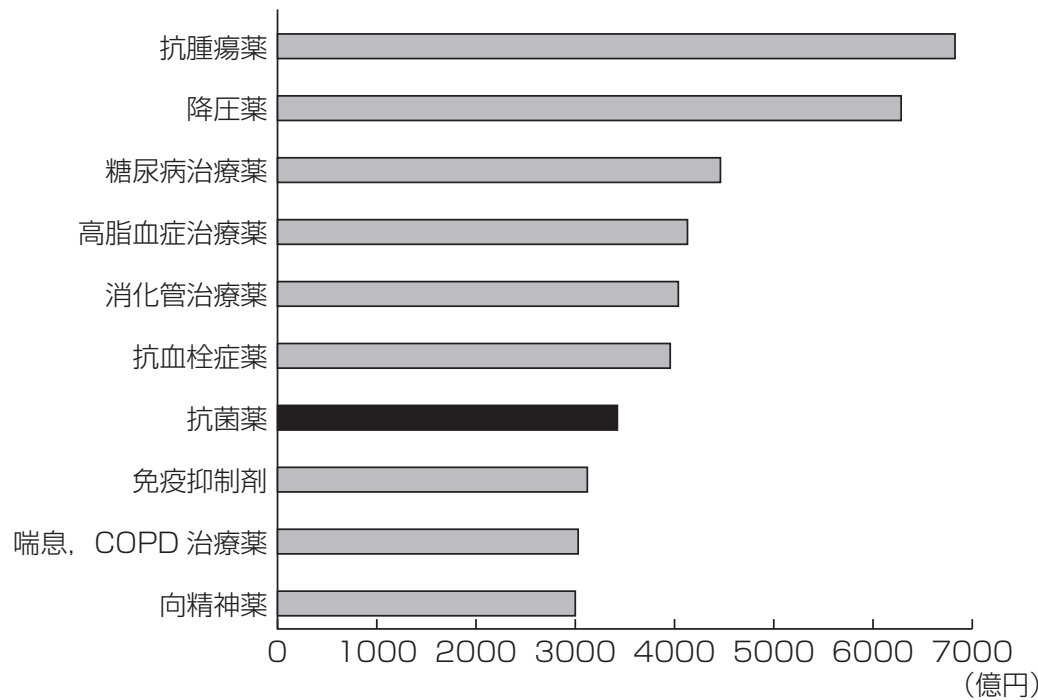

（億円）

文献 5 をもとに筆者作成

図 3. 国内の売り上げトップ 10 の薬効（2013 年）

継続的に使用される慢性疾患の治療薬などに比 べると，製薬会社にとって利益をあまり生み出 さない抗菌薬を開発するメリットは少ないと言 える ${ }^{6}$.

\section{7. 抗菌薬開発が抱える問題点}

上記のように，製薬企業は収益性が低いため に抗菌薬開発から撤退した，という説明は誤り ではないと思われる。ただし，それだけで一義 的に理由を説明するのも偏った見方であり，そ れ以外にも考えておかなければいけない背景が いくつか挙げられる7 . その 1 つは, 画期的な抗 菌薬を開発する難しさである. 新しい抗菌薬に 求められることは, 従来にない作用や特徵を有 する薬剤であるが，これまでに多くの抗菌薬が 開発されたことで，そのような画期的な薬凨を 開発することは難しくなっている.

次に抗菌薬開発にかかる費用も大きな課題と なる，抗菌薬に限らず，新薬の開発には膨大な 費用が必要であるが，全ての新薬が開発を成功 するわけではなく，製薬会社はそのリスクを背
負わなければならない.

また, 抗菌薬の開発に必要な期間の長さも重 要である. 図 4 はこれまでに開発された主要な 抗菌薬が発見から発売に至るまでの期間を示し ているが, 1990 年代頃までは 5〜10 年で開発で きた薬片が, 最近では 10〜20 年, あるいはそれ 以上の期間を要している.抗菌薬の開発は種(シー ズ）となる有望な物質を数多くの候補の中から スクリーニングして見つけ出し, それを長い年 月をかけて有効性や安全性を評価していく作業 であり，種から大木まで成長できるのはごくわ ずかであると言える。このように長い年月をか けてようやく利益を生み出す新薬の開発を続け ていくためには, 製薬企業は長期的展望に立っ た戦略が必要であり, 株主の厳しい要求にも応 えなければならない困難さもあると思われる.

さらに新規抗菌薬の開発に大きなハードルと なっているのが許認可の問題である. 新薬は承 認を得るまでに, 基礎的な評価や臨床治験の課 程で有効性や安全性を証明しなければならない. 以前に比べると, この評価の基準も厳しくなっ てきており, 開発途中で断念せざるを得なくな 


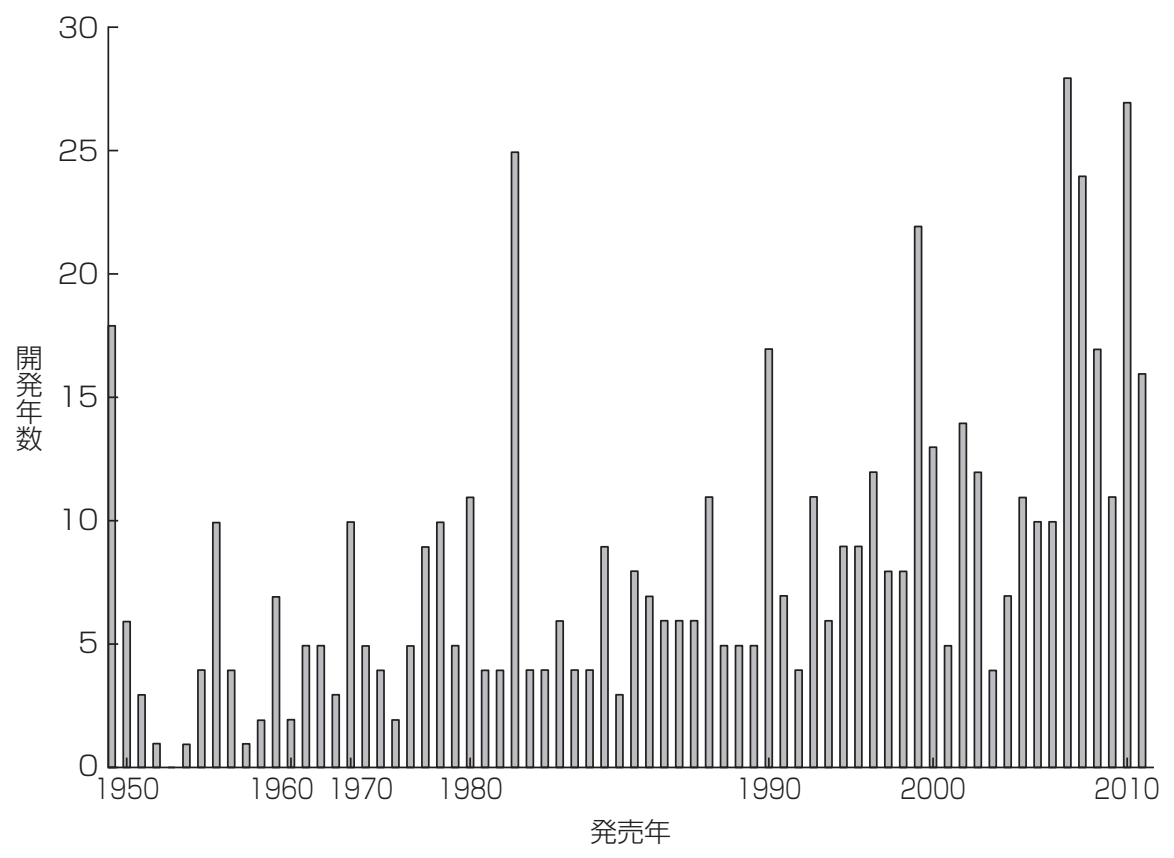

図 4. 新規抗菌薬の発見から発売に要する期間の推移

る抗菌薬も多い.

\section{8. 現在の抗菌薬の開発状況}

表 3 は国内外で現在開発中の抗菌薬をまとめ たものである．一見すると数多くの抗菌薬が開 発されており，これまで述べてきたことと矛盾 しているように思われる。ただし，以前はこれ と比べものにならないくらい数多くの抗菌薬が 開発されていたため, 現在の抗菌薬開発が盛ん であるとは言い難い.また，これまで多くの薬 剂が途中で開発を断念せざるを得ない状況にあっ たことを考慮すると，実際に臨床で使用できる ようになる薬剤はこの表の中の一部と考えられ る.

抗菌薬に限定されるわけではないが, 多くの 薬剂が開発途中で断念され, 世に出なくなる現 実を「死の谷 (death valley)」と呼んでいる. 開 発が中止に至る理由は様々であるが, 薬剤自体 に有効性や副作用の面で問題が生じた場合だけ
でなく, 開発の段階で承認機関が求める条件を クリアできなかった場合もある，また，欧米で は特にベンチャー企業を主体とした新薬の開発 が盛んであり, 抗菌薬も数多くのベンチャー企 業の挑戦の中から有望な薬剂が生み出されてい る場合が多いため, 開発に必要な莫大な資金が 調達できず企業自ら断念することもある.

\section{9. 抗菌薬の開発とドラッグ・ラグ}

開発された抗菌薬は正式にそれぞれの国の承 認を得ることで, 実際に臨床の現場で使用可能 となる，本来であれば，承認の時期に多少のず れが生じることはあっても, 使用可能な抗菌薬 の種類に違いはないはずである. しかし, 現状 では海外ですでに使用されているにもかかわら ず，国内ではまだ使用不可能な状態に置かれて いる抗菌薬が少なからず存在する。 これを一般 的にドラッグ・ラグ (drug lag) と呼んでいる. その 1 例としてコリスチンが挙げられ, 現在, 
表 3. 国内外の新規抗菌薬の開発状況

\begin{tabular}{|c|c|c|c|c|}
\hline 抗菌薬 & 分類 & 企業 & 欧米 & 国内 \\
\hline Ceftaroline & 抗MRSAセフェム & Forest, AstraZeneca, 大日本住友製薬 & 承認済 & phase 1 \\
\hline Ceftobiprole & セフェム & Basilea & EUで承認済 & 未開発 \\
\hline S-649266 & セフェム & 塩野義製薬 & phase 1 (米国) & phase 1 \\
\hline Ceftolozane/TAZ & セフェム+BLI & Cubist & phase 3 & 未開発 \\
\hline Ceftazidime/AVI & セフェム +BLI & AstraZeneca, Forest & phase 3 & phase 3 \\
\hline Ceftaroline/AVI & セフェム+BLI & Forest & phase 2 & 未開発 \\
\hline MK-7655 & $\mathrm{BLI}$ & Merck & phase 2 & 末開発 \\
\hline BIPM/RPX7009 & カルバペネム+BLI & Rempex & phase 1 (米国) & 未開発 \\
\hline BAL-30072 & $\mathrm{BLI}$ & Basilea & phase 1 (EU) & 末開発 \\
\hline Aztreonam/Avi & モノバクタム+BLI & AstraZeneca & phase 1 (EU) & 未開発 \\
\hline Delafloxacin & キノロン & Melinta & phase 3 & 未開発 \\
\hline Nemonoxacin & キノロン & WarnerChilcott & phase 3（米国） & 未開発 \\
\hline Avarofloxacin & キノロン & Furiex & phase 2 & 未開発 \\
\hline Zabofloxacin & キノロン & Paramount & phase 2（米国） & 未開発 \\
\hline Finafloxacin & キノロン & MerLion & phase 2（米国） & 未開発 \\
\hline KPI- 10 & キノロン & Kalidex & phase 1（米国） & 未開発 \\
\hline DS-8587 & キノロン & 第一三共 & 未開発 & phase 1 \\
\hline KRP-AM 1977 & キノロン & 杏林 & 未開発 & phase 1 \\
\hline GSK-2 140944 & Gyr/Topo阻害 & GSK & phase 1 & 未開発 \\
\hline AZD-0914 & Gyr/Topo阻害 & AstraZeneca & phase 1（米国） & 末開発 \\
\hline Tedizolid & オキサゾリジノン & Cubist, Bayer & $\begin{array}{c}\text { 承認済み (米国), } \\
\text { phase } 3 \text { (EU) }\end{array}$ & phase 3 \\
\hline Radezolid & オキサゾリジノン & Melinta & phase 2（米国） & 未開発 \\
\hline$M R X-1$ & オキサゾリジノン & MicuRx & phase 1 (米国) & 未開発 \\
\hline Dalbavancin & グリコペプチド & Durata & $\begin{array}{c}\text { 承認済み (米国), } \\
\text { phase } 3 \text { (EU) }\end{array}$ & 未開発 \\
\hline Oritavancin & グリコペプチド & TheMedicines & phase 3 & 未開発 \\
\hline TD-1792 & ヘテロダイマー & Theravance & phase 2（米国） & 未開発 \\
\hline TD-1607 & ヘテロダイマー & Theravance & phase 1 (米国) & 未開発 \\
\hline Omadacycline & テトラサイクリン & Paratek & $\begin{array}{c}\text { phase } 3 \text { (米国), } \\
\text { phase } 1 \text { (EU) }\end{array}$ & 末開発 \\
\hline Eravacycline & テトラサイクリン & Tetraphase & $\begin{array}{c}\text { phase } 3 \text { (米国), } \\
\text { phase } 2 \text { (EU) }\end{array}$ & 未開発 \\
\hline Solithromycin & ケトライド & Cempra, 富山化学 & phase 3（米国, EU) & phase 1 \\
\hline Plazomicin & アミノグリコシド & Achaogen & phase 2（米国） & 未開発 \\
\hline
\end{tabular}

BLI : $\beta$-ラクタマーゼ阻害薬

国内でもようやく承認に向けた手続きが進めら れているが, 海外では通常使用される抗菌薬の 中の 1 つに過ぎない. 国内でどうしても使用し たい場合は医師の個人輸入に頼るしかないが, 様々な制限がある。このように，ある薬剤が国 内の承認を受けていないために，海外であれば 助かる感染症が国内では治療できないという現 実を私たちはもっと強く認識する必要があると 思われる。
さらに，表 3 にも示すとおり，欧米では盛ん に開発されている抗菌薬が，まだ日本では開発 段階にも至っていないものが数多くみられる. これによりドラッグ・ラグの問題は今後さらに 深刻になると予想される。この問題を解決する には，国の新薬の承認のあり方の検討や，国内 でも開発が進めやすい環境作りが必要と思われ る. 


\section{0. 抗菌薬の開発を促進する動き}

抗菌薬開発の停滞と菌の耐性化の問題は, 海 外ではかなり危機感を持って受け止められ，そ の解決に向けた活動も行われている ${ }^{8)}$. 米国では 米国感染症学会 (Infectious Diseases Society of America：IDSA）が中心となり, 大学などの研 究機関, 行政, 製薬企業が一体となって新薬の 開発に取り組む活動を進めている.「The $10 \times 20$ Initiative $」$ プロジェクトと呼ばれるこのプロジェ クトは 2020 年までに 10 個の新しい抗菌薬を創 出することを目標としている ${ }^{9)}$. 行政側もこの活 動を支援するために, GAIN ACT法案(The Generating Antibiotic Incentives Now Act of 2011) という法律を施行し, 米国Food and Drug Administration（FDA）による審査期間の短縮 や 5 年間の市場独占期間の延長などを含めた優 遇策を実施している.

EUにおいては, 欧州製薬団体連合会(European Federation of Pharmaceutical Industries and Associations : EFPIA) と組んで, 官民が協力し て新薬を開発するプロジェクトを支援している. 革新的医薬品イニシアティブ (Innovative Medicines Initiative : IMI) と呼ばれるこの活動では, コンソーシアムによる情報共有や共同研究の推 進を柱とし, 抗菌薬だけが対象ではないが総額 2 億 4,600 万ユーロの助成を行っている.

日本においては, 日本化学療法学会が中心と なり創薬促進検討委員会 (委員長：舘田一博)が 発足しており, 日本感染症学会, 日本臨床微生 物学会, 日本環境感染学会, 日本細菌学会, 日 本薬学会とともに, 新規抗菌薬の開発に向けた 6 学会提言 ${ }^{10)}$ をまめ, 関係省庁をはじめ, 企業, 大学・研究機関，さらに一般の国民の方々にも 広く抗菌薬開発の必要性を認識してもらう活動 を始めている。ただし，国内における活動はま だ始まったばかりであり，具体的な成果はこれ からの活動に期待される.

\section{1. 現時点において実施できる対策}

これまで述べてきたように抗菌薬の開発はか なり時間のかかることであり, 今すぐに取り組 んだとしてもその成果が得られるのはまだ先の ことになる。 そのような状況において, 臨床の 現場ですぐに取り組むべき対策は「抗菌薬の適 正使用」であり, 現在使える抗菌薬をいかに温 存してその有効性を長く保たせるかにある．抗 菌薬を適正に使用するポイントとしては,「Hit fast, Hit hard!」と称されるように, 症例に応 じて適切な抗菌薬を選択し, 早期から十分な投 与を行うことが重要である. その後, こまめに 治療効果を評価しながらダラダラと長期間使用 しないことも大切である。そのためには培養を はじめとする細菌検査を意らず，検査結果を参 考にしながら治療薬の見直しを行う必要がある.

\section{おわりに}

新薬の開発については, 抗菌薬だけを特別扱 いすべきではないというご意見もあると思われ る。ただし，私たちが予想する以上に耐性菌の 問題は深刻になってきており，これに対抗する 手段としての新薬の開発は今後の感染症診療を 左右する重大な事項である。新規抗菌薬の開発 が停滞している背景には複雑な要因があり, 企 業だけにその責任を押しつけるのは適切ではな いと思われる. 今後の問題の打開には, 抗菌薬 の創薬に向けた環境作りが必要であり, 企業と ともに大学・研究機関, 学会が上手く連携し, 政府や関係省庁がそれを積極的に後押ししても らう必要がある。内科の医師だけでなく，医療 に携わる多くの方々にこの状況をご理解いただ き，新規抗菌薬の開発についてご賛同を賜るこ とができればと思っている.

著者のCOI (conflicts of interest) 開示 : 松本哲哉 ; 講演料 
(MSD, ファイザー, Meiji Seikaファルマ)

\section{文献}

1) World Health Organization : The top 10 causes of death. http://www.who.int/mediacentre/factsheets/fs310/en/

2) Chan $M:$ Antimicrobial resistance: no action today, no cure tomorrow. World Health Organization. http://ww w.who.int/dg/speeches/2011/WHD_20110407/en/

3) IDSA, Antibiotic Resistance Fact Sheet 2013. http://w ww.idsociety.org/AntibioticResistanceFactSheet-April 2013.pdf

4）八木澤守正：抗菌薬開発の現状と展望. 日本化療誌 52 : 761-770, 2004.

5）アイ・エム・エス・ジャパン：医薬品市場統計. Medicament News $2152: 2014$.

6) Spellberg B:New Antibiotic Development:Barriers and Opportunities in 2012. Alliance for the Prudent Use of
Antibiotics. http://www.tufts.edu/med/apua/news/ne ws-newsletter-vol-30-no-1-2.shtml

7) Cole ST: Who will develop new antibacterial agents? Philos Trans R Soc Lond B Biol Sci 369, 2014.

8) National Research Council : Technological Challenges in Antibiotic Discovery and Development:A Workshop Summary. National Academies Press(US). 2014. http://w ww.ncbi.nlm.nih.gov/books/NBK200814/

9) Infectious Diseases Society of America : The $10 \mathrm{x}$ '20 Initiative: pursuing a global commitment to develop 10 new antibacterial drugs by 2020 . Clin Infect Dis 50 :10811083, 2010.

10）日本化学療法学会 : 新規抗菌薬の開発に向けた 6 学会提 言 耐性菌の現状と抗菌薬開発の必要性を知っていただ くために. http://www.chemotherapy.or.jp/notice/168 _1.pdf 